\title{
Experimental treatment with sodium stibogluconate of hamsters infected with Leishmania (Leishmania) chagasi and Leishmania (Leishmania) a mazonensis
}

\author{
Tratamento experimental com stibogluconato de sódio em hamsters \\ infectados com Leishmania (Leishmania) chagasi e \\ Leishmania (Leishmania) amazonensis
}

\author{
Elizabeth M. de Figueiredo, Jaime Costa e Silva and Reginaldo P. Brazil
}

\begin{abstract}
The present paper reports the experimental treatment of hamsters infected with Leishmania chagasi and Leishmania amazonensis with sodium stibogluconate $(20 \mathrm{mg} / \mathrm{kg} / \mathrm{day} x$ 20 days). Only with $\mathrm{L}$. chagasi did the treatment result in the complete elimination of parasites from the spleen. However, no parasitological cure was achieved in hamsters infected with L. amazonensis.
\end{abstract}

Key-words: Leishmania. Sodium stibogluconate. Treatment.

Resumo O presente trabalho é um relato do tratamento experimental de hamsters infectado com Leishmania chagasi e Leishmania amazonensis com o stibogluconato de sódio (20mg/kg/dia x 20 dias). Somente na infeccção com L. chagasi, o tratamento resultou em completa eliminação dos parasitos do baço. Entretanto, não houve cura parasitologica em hamsters infectados com L. amazonensis.

Palavras-chaves: Leishmania. Stibogluconato de sódio. Tratamento.

Leishmaniases are diseases caused by several species of Leishmania (Ross, 1903) and both visceral and cutaneous leishmaniasis are regarded by the World Health Organization (WHO) as two of most important health problems in the world. Pentavalent antimonials are currently used in the treatment of both clinical forms. They are avaliable as meglumine antimoniate, which is generally referred to as glucantime (Rhône Poulenc, Paris, France) and is used in Latin America and French-speaking countries. Sodium stibogluconate referred to as Pentostan (Wellcome Foundation, London, UK), is used in Englishspeaking countries. In 1982, the World Health Organization (TDR/CHEMLEISH/VL, 1982) recommended a regimen of $20 \mathrm{mg} / \mathrm{kg} /$ day of pentavalent antimonial for treating leishmaniasis instead of $10 \mathrm{mg} / \mathrm{kg} / \mathrm{day}$ as previously recommended 1 . In this preliminary report, we evaluate the action of sodium stibogluconate produced by Shandong Xinhua Pharmaceutical Factory, China, which is now avaliable in Brazil through the Ministry of Health (FNS) for the treatment of cutaneous and visceral leishmaniasis as a substitute for meglumine antimoniate (Glucantime $\AA$ ). Males of outbred hamsters (Mesocriscetus auratus), weighing 90-110g were infected with the reference strains: Leishmania (L.) chagasi (MHOM/BR/74/PP75) isolated from a case of visceral leishmaniasis in Ituaçu, Bahia State, Brazil and Leishmania (L.) amazonensis (IFLA/BR67/PH8) isolated from Lutzomyia

\footnotetext{
Laboratório de Leishmanioses, Centro de Pesquisas René Rachou/FIOCRUZ. Fundação Nacional de Saúde, Belo Horizonte, MG, Brasil. This work has been supported by CNPq and FIOCRUZ.

Address to: Dr.Reginaldo P. Brazil. Laboratório de Leishmanioses/CPqRR/FIOCRUZ. Av. Augusto de Lima 1715, $30190-002$ Belo Horizonte, MG, Brasil. Fax: +55 31 295-3115.

Recebido para publicação em 12/12/97.
} 
flaviscutellata in Utinga, Pará State, Brazil. In the first group, 20 hamsters were inoculated intraperitoneally with $0.1 \mathrm{ml}$ of phosphate-buffered saline containing 107 amastigotes of $L$. chagasi obtained from a spleen suspension of previously infected hamsters. In the second group, 20 hamsters were inoculated subcutaneously in the nose with $0.1 \mathrm{ml}$ of phosphate-buffered saline containing 107 amastigotes of $L$. amazonensis from a suspension of nose tissue from a previously inoculated hamster. Sodium stibogluconate was administered to hamsters ten days after infection with the recommended dose of $20 \mathrm{mg} / \mathrm{kg} /$ day for 20 days by intramuscular (im) injection. Therapeutic activity in hamsters infected with L. chagasi was estimated 19 days after the end of the treatment by comparison with a control group. Spleens were weighed and measured at the end of the experiment and the number of parasites was determined in the spleen of each animal by counting 100 nuclei of cells in the imprint stained by Giemsa. For L. amazonensis infection, the development of the lesion was followed weekly for nine weeks by measuring the noses of treated and control hamsters with a caliper2. Thirty days after the end of treatment the animals were killed and the number of amastigotes was determined in the imprint of the lesion. The results were compared with control groups using analysis of variance in the Minitab program. Sodium stibogluconate was effective against $L$. chagasi infection with complete clearance of amastigotes in the spleen of the treated group. In control animals, parasites were present $(x=9.1 \pm 6.2$ amastigotes/100 cells). No significant difference was detected in the weight $(0.05<p=0.506)$, length $(0.05<p=0.153)$ or width $(0.05<p=0.113)$ of the spleens of treated animals when compared with controls. This could be explained by the low parasitism of the spleen at the end of the experiment which was not enough to show any clinical alteration of the organ.

Despite a slight clinical improvement (Figure 1), amastigote clearance was not achieved with the recommended dose of $20 \mathrm{mg} / \mathrm{kg} /$ day in the treatment of cutaneous leishmaniasis caused by

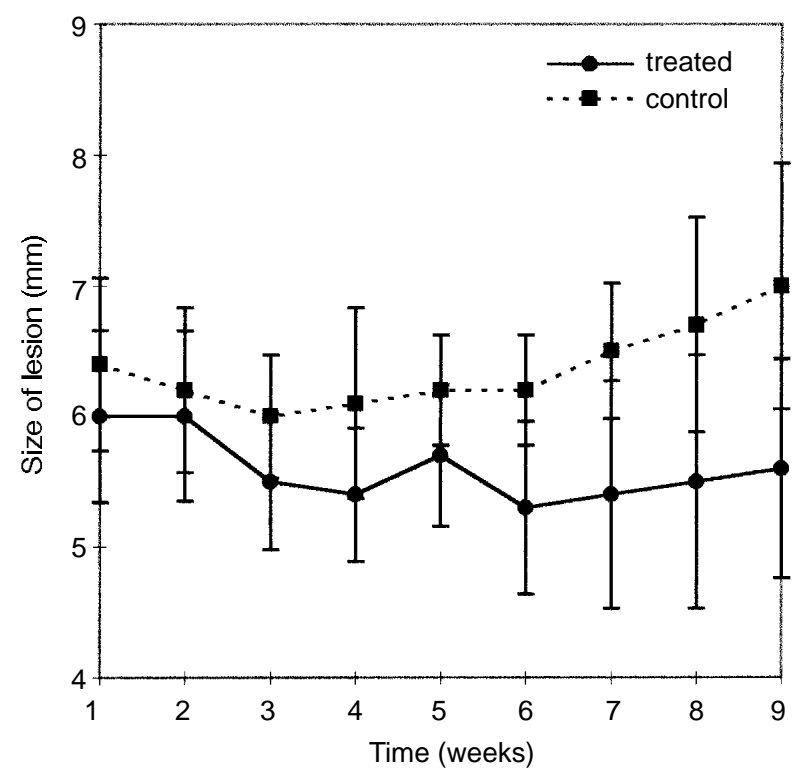

Figure 1 - Clinical evaluation of hamsters infected with Leishmania (L.) amazonensis and treated with sodium stibogluconate.

L. amazonensis, as demonstrated by the presence of large numbers of amastigotes in the treated group at the end of the experiment. This result has important implications since this drug is now being distributed by the Health Authorities (FNS) for the treatment of both visceral and cutaneous leishmaniases in Brazil even though there was no previous experimental evaluation of this drug against any Brazilian species of Leishmania. 


\section{REFERENCES}

1. Herwaldt BL, Berman JD. Recomendations for treating leishmaniasis with sodium stibogluconate (Pentostam $\AA$ ) and review of pertinent clinical studies. American Journal of Tropical Medicine and Hygiene 46:296-306, 1992.
2. Neal R. Effect of dihydrofolate reductase inhibitors on experimental cutaneous leishmaniasis with special emphasis on leishmaniasis isolates from Latin America. Revista do Instituto de Medicina Tropical de São Paulo 14:341-351, 1972. 